\title{
PEMODELAN JUMLAH KEMATIAN BAYI DI JAWA TIMUR DENGAN GEOGRAPHICALLY WEIGHTED POISSON REGESSION (GWPR)
}

\author{
Sisvia Cahya Kurniawati, Kuntoro \\ Departemen Biostatistika dan Kependudukan FKM UNAIR \\ Fakultas Kesehatan Masyarakat Universitas Airlangga \\ Kampus C Unair Mulyorejo Surabaya 60115 \\ Email : sisvia.cahya@gmail.com
}

\begin{abstract}
Abstrak
Kematian bayi merupakan salah satu indikator pembangunan kesehatan. Pembangunan kesehatan agar berhasil dibutuhkan adanya ketersediaan data/informasi yang akurat untuk mendukung proses pengambilan keputusan dan perencanaan program. Salah satu data informasi yang bisa digunakan adalah data spasial, dengan mengikutsertakan informasi koordinat lokasi karena kondisi geografis, sosial budaya dan ekonomi tentunya akan berbeda antara wilayah yang satu dengan wilayah yang lain, sehingga faktor yang berkontribusi terhadap kematian bayi antara wilayah satu dan wilayah yang lain juga akan berbeda. Oleh sebab itu penelitian ini menggunakan metode statistik Geographically Weighted Poisson Regression (GWPR) untuk mempermudah menggambarkan parameter lokal yang dapat menjelaskan variasi spasial dalam hubungan antara kasus kematian bayi di Jawa Timur dengan faktor yang berkontribusi. Sejumlah model harus dievaluasi dan nilai AIC untuk setiap model harus dibandingkan untuk mendapatkan model yang terbaik. Model yang terbaik adalah model dengan nilai AIC terendah. Hasil penelitian didapatkan bahwa terdapat perbedaan mengenai faktor yang signifikan terhadap jumlah kematian bayi di kabupaten/kota di Provinsi Jawa Timur, faktor tersebut adalah jumlah fasilitas kesehatan, pertambahan Produk Domestik Regional Bruto (konstan), Angka Melek Huruf (AMH), persentase imunisasi dasar lengkap, dan persentase persalinan non medis. Nilai AIC antara model regresi global dan model GWPR dilakukan perbandingan, diketahui bahwa model GWPR merupakan model yang lebih baik untuk menganalisa data AKB di Provinsi Jawa Timur.
\end{abstract}

Kata Kunci: kematian bayi, Geographically Weighted Poisson Regression (GWPR)

\section{PENDAHULUAN}

\section{Latar Belakang}

Pembangunan kesehatan, termasuk peningkatan derajat kesehatan merupakan bagian yang tidak terpisahkan dari pembangunan nasional yang harus terus menerus diupayakan oleh pemerintah. Selain angka kematian ibu (Maternal Mortality Rate (MMR)), indikator lain yang juga digunakan sebagai tolak ukur kemajuan hasil pembangunan di bidang kesehatan adalah Angka Kematian Bayi (Infant Mortality Rate (IMR)). Angka Kematian Bayi dapat menggambarkan tingkat kesehatan bayi mulai lahir sampai dengan umur 11 bulan. Angka ini menunjukkan banyaknya bayi yang meninggal sebelum mencapai usia 1 (satu) tahun per 1.000 kelahiran hidup (Pickett, George et al, 2009).

Berdasarkan Laporan Eksekutif Kesehatan Provinsi Jawa Timur 2012 perkembangan selama lima tahun terakhir menunjukkan bahwa tren AKB di Jawa Timur cenderung menurun yaitu $31,58 \mathrm{di}$ tahun 2008 menurun hingga 28,31 pada tahun 2012. Secara umum di wilayah Jatim mengalami penurunan $A K B$, namun masih ada beberapa daerah dengan $A K B$ yang cukup tinggi sehingga memerlukan perhatian lebih dari pemerintah. Sebanyak 8 daerah dengan AKB diatas 50, antara lain Kabupaten Probolinggo $(63,51)$, Kabupaten Jember $(56,33)$, Kabupaten Situbondo $(54,94)$, Kabupaten Bangkalan (54,56), Kabupaten Sampang $(54,48)$, Kabupaten Bondowoso $(53,93)$, Kabupaten Pasuruan $(51,07)$ serta Kabupaten Pamekasan $(50,69)$ (BPS Jatim, 2013).

Data di atas menunjukkan bahwa AKB di Jawa Timur bervariasi. Kabupten/kota di Jawa Timur memiliki kondisi geografis, sosial budaya dan ekonomi yang berbeda sehingga faktor yang berkontribusi terhadap kematian bayi antara wilayah satu dan wilayah yang lain juga akan berbeda. Oleh karena itu diperlukan metode statistik yang dapat merepresentasikan kondisi lokal dari suatu wilayah tertentu yaitu dengan menggunakan Geographically Weighted Poisson 
Regression (GWPR). Metode statistik ini adalah metode yang telah dikembangkan dengan memperhitungkan faktor spasial. GWPR merupakan pengembangan dari regresi Poisson akan tetapi yang membedakan dalam metode GWPR memperhatikan pembobot berupa letak lintang dan letak bujur dari titik pengamatan yang diamati. Sehingga dalam model GWPR variabel respon dipengaruhi oleh variabel prediktor yang koefisien regresinya dipengaruhi letak geografis. Menurut Nakaya, et.al (2005), model GWPR menghasilkan penaksiran parameter model yang bersifat lokal untuk setiap titik pengamatan.

Tujuan penelitian ini adalah untuk menggambarkan parameter lokal yang dapat menjelaskan variasi spasial dalam hubungan antara kasus kematian bayi di Jawa Timur dengan faktor yang berkontribusi dengan menggunakan model Geographically Weighted Poisson Regression (GWPR).

\section{METODOLOGI PENELITIAN}

Data yang digunakan dalam penelitian ini adalah data sekunder yang berasal dari hasil Survei Sosial Ekonomi Nasional(SUSENAS) tahun 2012 yang telah dipublikasikan oleh Badan Pusat Statistik dan Profil Kesehatan Provinsi Jawa Timur tahun 2012. Variabel yang digunakan dalam penelitian ini terbagi menjadi 2 yaitu variabel $Y$ (respon) atau dependen dan variabel $X$ (prediktor) atau independen serta letak lintang selatan $\left(u_{i}\right)$ dan letak bujut timur $\left(v_{i}\right)$. Variabel tersebut antara lain jumlah kematian bayi (Y), jumlah fasilitas kesehatan $\left(X_{1}\right)$, jumlah tenaga medis $\left(X_{2}\right)$, Produk Domestik Regional Bersih (konstan) $\left(X_{3}\right)$, Angka Melek Huruf $(\mathrm{AMH})\left(\mathrm{X}_{4}\right)$, rata-rata lama sekolah $\left(X_{5}\right)$, persentase air bersih $\left(X_{6}\right)$, imunisasi dasar lengkap $\left(X_{7}\right)$, persentase persalinan non medis $\left(X_{8}\right)$. Selain itu juga letak astronomi (letak lintang dan bujur) 38 Kabupaten/Kota di Provinsi Jawa Timur.

Langkah-langkah penelitian ini adalah sebagai berikut: mendeskripsikan variabel respon $(\mathrm{Y})$ dan variabel prediktor $(X)$, mengidentifikasi dan menyelesaikan kasus mutikolinieritas. Langkah selanjutnya mendapatkan model terbaik dari Regresi Poisson dan mendapatkan model terbaik dari GWPR pada pemodelan jumlah kematian bayi yang terjadi di kabupaten/kota Jawa Timur.
Pemodelan GWPR didapatkan dengan cara menghitung jarak Euclidian untuk mendapatkan matriks pembobot pada masing-masing fungsi pembobot, menentukan bandwith optimum untuk setiap obyek, melakukan penaksiran parameter model GWPR, dan menguji signifikansi parameter model GWPR.

\section{HASIL DAN PEMBAHASAN \\ Statistik Deskriptif}

Statistik deskriptif adalah bagian statistik yang membahas tentang metode untuk menyajikan data sehingga dapat diartikan sebagai metode yang berkaitan dengan pengumpulan dan penyajian suatu gugus data sehingga memberikan informasi yang berguna. Tabel 1 memaparkan jumlah kasus kematian bayi di Jawa Timur tahun 2012 dan faktor yang diduga berkontribusi terhadap jumlah kematian bayi.

Tabel 1. Statistika Deskriptif Variabel Penelitian

\begin{tabular}{lllll}
\hline & Min & Max & Mean & Varian \\
\hline$Y$ & 23 & 424 & 155,37 & $9,9 \times 10^{3}$ \\
$X_{1}$ & 218 & 3248 & $1,5 \times 10^{3}$ & $6,4 \times 10^{5}$ \\
$X_{2}$ & 16 & 7118 & 1242,7 & $1,4 \times 10^{6}$ \\
$X_{3}$ & $1,7 \times 10^{5}$ & $1,02 \times 10^{8}$ & $9,9 \times 10^{6}$ & $2,8 \times 10^{14}$ \\
$X_{4}$ & 69,11 & 98,35 & 90,023 & 47,337 \\
$X_{5}$ & 4,22 & 10,87 & 7,6947 & 2,383 \\
$X_{6}$ & 21,38 & 100,00 & 86,588 & 308,069 \\
$X_{7}$ & 6,60 & 95,63 & 54,712 & 424,749 \\
$X_{8}$ & $-1,41$ & 24,98 & 11,059 & 46,103 \\
\hline
\end{tabular}

Tahun 2012 rata-rata jumlah kematian bayi di kabupaten/kota Provinsi Jawa Timur sebesar 155 jiwa. Sedangkan jumlah kematian bayi memiliki varian sebesar $9,9 \times 10^{3}$ yang berarti varian dari kasus kematian bayi di Jawa Timur cukup besar. Di beberapa kabupaten/kota di Jawa Timur jumlah kematian bayi berjumlah puluhan sampai ratusan kasus kematian.

\section{Model Regresi Poisson}

Langkah awal untuk analisis model GWPR dengan membentuk model regresi Poisson terlebih dahulu. Uji kolinieritas perlu dilakukan lebih dulu untuk mengetahui apakah antara variabel prediktor telah memenuhi kondisi tidak saling berkorelasi. Beberapa kriteria yang dapat digunakan untuk mengetahui adanya kolinieritas diantara variabel prediktor antara lain dengan menggunakan koefisien korelasi (Person correlation) dan Variance Inflation Factors (VIF). 
Suatu data dikatakan multikolinieritas apabila nilai korelasi antar variabel prediktor relatif lebih tinggi dan nilai VIF lebih besar dari 10. Nilai korelasi yang dimiliki dapat juga dilihat nilai $p$ value antar variabel prediktor. Jika nilai $p$ value lebih kecil dari nilai alpha yaitu 0,05 maka dapat disimpulkan bahwa antar variabel prediktor memilki hubungan atau berkorelasi.

Variabel yang memiliki nilai korelasi yang besar adalah jumlah fasilitas kesehatan dan jumlah tenaga kesehatan, jumlah fasilitas kesehatan dan Produk Domestik Regional Bruto (PDRB), jumlah tenaga kesehatan dan PDRB, Angka Melek Huruf (AMH) dan rata-rata lama sekolah, $\mathrm{AMH}$ dan persentase imunisasi dasar lengkap, serta ratarata lama sekolah dan persentase persalinan non medis.

Tabel 2. Nilai VIF Masing-masing Variabel Prediktor

\begin{tabular}{lrrr}
\hline Model & \multicolumn{1}{c}{ B } & \multicolumn{1}{c}{ Tolerance } & \multicolumn{1}{c}{ VIF } \\
\hline (Constant) & $-2,900$ & & \\
$X_{1}$ & 0,096 & 0,286 & 3,493 \\
$X_{2}$ & 0,022 & 0,097 & 10,282 \\
$X_{3}$ & $-1,795 \times 10^{-6}$ & 0,139 & 7,215 \\
$X_{4}$ & 0,072 & 0,121 & 8,241 \\
$X_{5}$ & 8,850 & 0,095 & 10,576 \\
$X_{6}$ & $-0,095$ & 0,740 & 1,351 \\
$X_{7}$ & $-1,426$ & 0,651 & 1,535 \\
$X_{8}$ & 1,742 & 0,711 & 1,407 \\
\hline
\end{tabular}

Tabel 2 di atas menunjukkan terdapat 2 variabel yang memiliki nilai torelan $<0,1$ dan VIF $>10$, yaitu jumlah tenaga kesehatan dan lama sekolah. Kedua variabel tersebut tidak dapat diikutsertakan dalam pemodelan selanjutnya yaitu pemodelan regresi poisson dan GWPR. Pengujian kembali dilakukan apakah masih terdapat korelasi diantara variabel terpilih. Hasil pengujian didapatkan bahwa hasil nilai korelasi diantara variabel prediktor kurang dari 0,95 dan nilai VIF untuk semua variabel prediktor kurang dari 10 sehingga dapat dikatakan bahwa tidak terjadi kasus multikolinieritas sehingga variabelvariabel tersebut dapat digunakan dalam pembentukan model regresi Poisson. Pengujian serentak dalam model regresi Poisson dengan hipotesis sebagai berikut:

$H_{0:} \beta_{1}=\beta_{3}=\beta_{4}=\beta_{6}=\beta_{7}=\beta_{10}=0$

$\mathrm{H}_{1}$ : paling sedikit ada satu $\beta_{\mathrm{j}} \neq 0$
Nilai $\mathrm{D}(\hat{\beta})$ sebesar 1536,928. Nilai devians kemudian dibandingkan dengan nilai Chi Square dengan taraf signifikan sebesar $5 \%$. Nilai $\mathrm{D}(\hat{\beta})>\mathrm{X}^{2}{ }_{(0.05,6)}(12,59159)$ sehingga dapat diambil kesimpulan tolak $\mathrm{H}_{0}$ yang mempunyai arti bahwa terdapat satu parameter yang berpengaruh secara signifikan terhadap model. Langkah selanjutnya adalah melakukan pengujian secara parsial untuk mencari parameter mana yang berpengaruh secara signifikan terhadap model. Hipotesis dari pengujian secara parsial adalah sebagai berikut:

$H_{0}: \beta_{j}=0$

$H_{1}: \beta_{j} \neq 0 ; j=1,3,4,6,7,8$

Tabel 3. Estimasi Parameter Model Regresi Poisson

\begin{tabular}{llll}
\hline Parameter & B & Z & Sig \\
\hline (Intercept) & 3,594 & 12,3803 & 0,000 \\
$X_{1}$ & 0,001 & 45.87155 & 0,000 \\
$X_{3}$ & $-5,140 \times 10^{-9}$ & $-5,341$ & 0,000 \\
$X_{4}$ & 0,012 & 4 & 0,000 \\
$X_{6}$ & 0,000 & 0 & 0,435 \\
$X_{7}$ & $-0,012$ & -15 & 0,000 \\
$X_{8}$ & 0,006 & 2.5 & 0,007 \\
\hline
\end{tabular}

Hasil analisis dapat dilihat pada tabel 3. Nilai $Z_{\text {hitung }}$ akan dibandingkan dengan nilai $Z_{\alpha / 2}$ dengan taraf signifikansi $5 \%$ yaitu 1,96 . Satu variabel memiliki nilai $Z_{\text {hitung }}<Z_{\alpha / 2}$, yaitu variabel $X_{6}$. Sehingga variabel yang berpengaruh secara signifikan adalah variabel $X_{1}$ (jumlah fasilitas kesehatan), $X_{3}$ (PDRB), $X_{4}(A M H), X_{7}$ (persentase Imunisasi Dasar Lengkap), dan $X_{8}$ (persentase Persalinan non medis).

Uji serentak dilakukan kembali pada pemodelan regresi poisson tanpa mengikutsertakan parameter $\mathrm{X}_{6}$ ke dalam pembentukan model. Nilai devians $\mathrm{D}(\hat{\beta})$ sebesar 1536,321. Nilai devians kemudian dibandingkan dengan nilai Chi Square dengan taraf signifikan sebesar $5 \%$. Nilai $\mathrm{D}(\hat{\beta})>\mathrm{X}_{(0.05,6)}(11.0705)$ sehingga keputusan tolak $\mathrm{H}_{0}$ yang mempunyai arti bahwa terdapat satu parameter yang berpengaruh secara signifikan terhadap model.

Parameter yang berpengaruh secara signifikan antara lain $\beta_{0}, \beta_{1}, \beta_{3}, \beta_{4}, \beta_{7}, \beta_{8}$, sehingga model regresi global dengan regresi Poisson yang dibentuk untuk jumlah kematian bayi di Provinsi Jawa Timur adalah 


$$
\begin{aligned}
(\hat{\mu})= & \exp \left(3,549+0,001 \mathrm{X}_{1}-5,140 \times 10^{-9} \mathrm{X}_{3}+0,0012 \mathrm{X}_{4}\right. \\
& \left.-0,0012 \mathrm{X}_{7}+0,006 \mathrm{X}_{8}\right)
\end{aligned}
$$

Langkah berikutnya adalah memeriksa kasus overdispersi pada model regresi Poisson dengan melihat nilai devians/db dan pearson chi square/db. Nilai devians/db dan pearson chi square/db lebih besar 1 sehingga disimpulkan bahwa regresi Poisson jumlah kematian bayi di Jawa Timur mengalami overdispersi. Kasus overdispersi akan menyebabkan model yang terbentuk menjadi estimasi parameter yang bias. Oleh karena itu untuk mengatasi kasus overdispersi dapat menggunakan pemodelan dengan Geographically Weighted Poisson Regression (GWPR).

\section{Model GWPR}

Langkah pertama adalah mengidentifikasi heterogenitas spasial pada regresi dengan menggunakan uji Breusch Pagan. Berdasarkan pengolahan data diperoleh nilai statistik BP adalah 11,98437 dengan $p$ value sebesar 0,0350026 . Hal ini menunjukkan bukti yang signifikan adanya pengaruh heterogenitas spasial dalam model. Heterogenitas spasial mengindikasikan bahwa parameter model regresi dipengaruhi oleh faktor lokasi pengamatan, dalam hal ini adalah letak geografis kabupaten/kota.

Pengujian kesesuaian model dilakukan terlebih dahulu sebelum melakukan pengujian serentak dan pengujian parsial. Pengujian ini bertujuan untuk mengetahui apakah terdapat perbedaan antara regresi Poisson dengan model GWPR. Berikut ini adalah hipotesisnya:

$H_{0}: \beta_{j}\left(u_{i}, v_{i}\right)=\beta_{j} j=0,1,3,4,6,7,8$

$H_{1}: \beta_{j}\left(u_{i}, v_{i}\right) \neq \beta_{j}$

Uji kesesuaian model GWPR dengan menggunakan kernel fix Gaussian dilakukan dengan melihat nilai $F_{\text {hitung }}$ dibandingkan dengan $F_{\text {tabel. }}$ Nilai $F_{\text {hitung }}$ sebesar 0,992 dibandingkan dengan nilai $F_{\text {tabel }(0,05 ; 32 ; 17)}=2,136944$, sehingga dapat ditarik kesimpulan bahwa gagal tolak $\mathrm{H}_{0}$ karena $F_{\text {hitung }}<\mathrm{F}_{(0,05 ; 32 ; 17)}$, maka dapat dikatakan dengan taraf signifikansi $5 \%$ tidak terjadi adanya perbedaan antara model poisson dengan model GWPR.
Pengujian berikutnya adalah pengujian parameter secara serentak dari model GWPR. Berikut ini adalah hipotesisnya:

$$
\begin{aligned}
\mathrm{H}_{0}: \beta_{1}\left(\mathrm{u}_{1}, \mathrm{v}_{1}\right) & =\beta_{3}\left(\mathrm{u}_{3}, \mathrm{v}_{3}\right)=\beta_{4}\left(\mathrm{u}_{4}, \mathrm{v}_{4}\right)=\beta_{7}\left(\mathrm{u}_{7}, \mathrm{v}_{7}\right)= \\
\beta_{8}\left(\mathrm{u}_{8}, \mathrm{v}_{8}\right) & =0
\end{aligned}
$$$$
\mathrm{H}_{1} \text { : paling tidak ada salah satu } \beta_{\mathrm{j}}\left(\mathrm{u}_{\mathrm{i}}, \mathrm{v}_{\mathrm{i}}\right) \neq 0
$$

Nilai devians $\mathrm{D}(\hat{\beta})$ sebesar 548,813661 dan nilai $\mathrm{X}^{2}{ }_{(0.05 ; 5)}$ sebesar 11.0705 berarti tolak $\mathrm{H}_{0}$ karena nilai $\mathrm{D}(\hat{\beta})>X^{2}{ }_{(0.05 ; 5)}$. Kesimpulannya minimal ada satu parameter yang berpengaruh terhadap model secara signifikan.

Pengujian parsial dimaksudkan untuk mengetahui variabel mana saja yang berpengaruh secara signifikan terhadap model dengan hipotesis sebagai berikut.

$H_{0}: \beta_{j}\left(u_{i}, v_{i}\right)=0$

$H_{1}: \beta_{j}\left(u_{i}, v_{i}\right) \neq 0$

Tabel 4 menunjukkan variabel yang berpengaruh secara signifikan dengan melihat nilai $\left|Z_{\text {hitung }}\right|>$ $Z_{\alpha / 2}$ dengan taraf signifikansinya sebesar $5 \%$ dimana $Z_{\text {tabel }}$ atau $Z_{\alpha / 2}=1,96$. Berdasarkan data pada tabel 4 , semua variabel signifikan sehingga pemodelannya adalah sebagai berikut: $\ln \left(\hat{\mu}_{\mathrm{i}}\right)=4.916832+0,523413 \mathrm{X}_{1^{-}}$

$$
\begin{aligned}
& 0,089314 X_{3}+0,084337 X_{4}-0,245708 X_{7} \\
& +0,043885 X_{8}
\end{aligned}
$$

Tabel 4. Uji Parsial Model GWPR

\begin{tabular}{llll}
\hline Variabel & B & Std. Error & Zhitung \\
\hline Intercep & 4.916832 & 0.014737 & 333.64289 \\
$X_{1}$ & 0.523413 & 0.016449 & 31.820750 \\
$X_{3}$ & -0.089314 & 0.014286 & -6.251809 \\
$X_{4}$ & 0.084337 & 0.018858 & 4.472137 \\
$X_{7}$ & -0.245708 & 0.016504 & -14.887963 \\
$X_{8}$ & 0.043885 & 0.015871 & 2.765093 \\
\hline
\end{tabular}

Variabel pertama yang signifikan pada model menunjukkan bahwa setiap pertambahan jumlah fasilitas kesehatan, dengan asumsi nilai variabel lain tetap, maka jumlah kematian bayi cenderung bertambah sebanyak $\exp (0,5234) \approx 1$ jiwa. Fasilitas kesehatan yang tersedia diharapkan dapat mengurangi angka kematian bayi, akan tetapi dari pemodelan GWPR didapatkan bahwa jumlah kematian bayi cenderung bertambah apabila jumlah fasilitas kesehatan juga bertambah. Hasil analisis korelasi, jumlah fasilitas kesehatan berkorelasi kuat dengan jumlah tenaga 
kesehatan dan Produk Domestik Regional Bruto (konstan) (PDRB).

Menurut Depkes RI (2001) dalam Khudori (2012), faktor yang mempengaruhi keputusan masyarakat untuk memperoleh pelayanan kesehatan adalah semakin tinggi status ekonomi maka semakin besar akan pembelian jasa atau barang, tuntutan kebutuhan yang spesifik terhadap pelayanan kesehatan individu yang mungkin pelayanan kesehatan individu tersebut tidak dapat diperoleh di Puskesmas. Masyarakat mengenali lebih baik perbedaan antara tempat pelayanan kesehatan yang ada berdasarkan pengalaman atau pengetahuan seseorang. Pertimbangan akan jarak tempuh yang mudah untuk mendapatkan pelayanan kesehatan yang ada terutama menghadapi kasus-kasus emergensi. Karakteristik penduduk yang mempunyai heterogenitas yang tinggi terdiri dari suku, etnis dan latar belakang yang berbeda sehingga menimbulkan perbedaan persepsi terhadap pelayanan kesehatan. Jaminan kesehatan yang dimiliki masyarakat misalnya Askes, Jamsostek dan jaminan kesehatan lainnya yang menganjurkan menggunakan fasilitas kesehatan di tempat yang sudah ditentukan.

Variabel kedua yang signifikan pada model menunjukkan bahwa setiap pertambahan PDRB (konstan), dengan asumsi nilai variabel lain tetap, maka jumlah kematian bayi cenderung berkurang sebanyak $\exp (0,089) \approx 1$ jiwa. Kasus kematian bayi yang terjadi di Indonesia masih tinggi, salah satunya karena disebabkan masih rendahnya pendapatan perkapita dari masyarakat yang dapat dilihat dari PDRB.

Semakian rendahnya nilai PDRB berarti semakin rendahnya kemakmuran masyarakat yang berarti terdapat masyarakat yang berada di bawah garis kemiskinan. Hal ini tentu berpengaruh terhadap gaya hidup masyarakat yang cenderung tidak sehat, seperti ibu mengandung yang tidak memperhatikan makanan yang bergizi, tidak memeriksakan kehamilannya, persalinan dengan fasilitas sangat minim karena ketidaksanggupan pembiayaan persalinan di fasilitas kesehatan.

Variabel ketiga yang signifikan pada model menunjukkan bahwa setiap pertambahan Angka
Melek Huruf, dengan asumsi nilai variabel lain tetap, maka jumlah kematian bayi cenderung bertambah sebanyak $\exp (0,084) \approx 1$ jiwa. Angka Melek Huruf (AMH). Angka Melek Huruf (AMH) adalah perbandingan antara jumlah penduduk usia 15 tahun ke atas yang atas yang dapat membaca dan menulis dengan jumlah penduduk usia 15 tahun ke atas. AMH berpengaruh terhadap kematian bayi karena berhubungan dengan pola asuh anak. Orang tua yang memiliki kemampuan membaca dapat lebih mudah mengakses informasi bila dibandingkan dengan orang tua yang tidak mempunyai kemampuan membaca. Oleh sebab itu AMH berpengaruh terhadap pola asuh anak atau kesejahteraan anak di wilayah tersebut. Akan tetapi pada model AMH justru cenderung menambah kasus kematian bayi. Berdasarkan nilai Pearson Correlation, AMH berkorelasi erat dengan rata-rata lama sekolah.

Rata- rata lama sekolah mengindikasikan makin tingginya pendidikan yang dicapai oleh masyarakat di suatu daerah. Semakin tinggi ratarata lama sekolah berarti semakin tinggi jenjang pendidikan yang dijalani. Asumsi yang berlaku secara umum bahwa semakin tinggi tingkat pendidikan seseorang maka semakin tinggi pula kualitas seseorang, baik pola pikir maupun pola tindakannya (Kumalasari, 2009).

Variabel keempat yang signifikan pada model menunjukkan bahwa setiap pertambahan persentase imunisasi dasar lengkap, dengan asumsi nilai variabel lain tetap, maka jumlah kematian bayi cenderung berkurang sebanyak $\exp (0,2457) \approx 1$ jiwa.

Program pengembangan imunisasi merupakan salah satu kegiatan yang mendapat prioritas dalam sistem kesehatan nasional. Program ini bertujuan untuk melindungi bayi dan balita dari PD3I (Penyakit yang dapat dicegah dengan imunisasi) seperti TBC, difteri, pertusis, tetanus, dan campak. Diperkirakan PD3I merupakan penyebab dari sekitar 48 kematian bayi dan 56 kematian balita per 1000 kelahiran hidup dalam kurun waktu satu tahun (IDAI, 2008).

Variabel kelima yang signifikan pada model menunjukkan bahwa setiap pertambahan persentase penolong persalinan non medis, 
dengan asumsi nilai variabel lain tetap, maka jumlah kematian bayi cenderung bertambah sebanyak exp $(0,044) \approx 1$ jiwa. Pertolongan persalinan oleh dukun masih diminati oleh masyarakat, karena pelayanan dukun mudah terjangkau, dan keakraban dengan pasien, bersedia merawat sampai 35-40 hari serta bersedia merawat bayi setelah melahirkan, membantu keluarga dan pekerjaan rumah tangga, dan berperan dalam berbagai upacara keselamatan (Depkes RI, 2003).

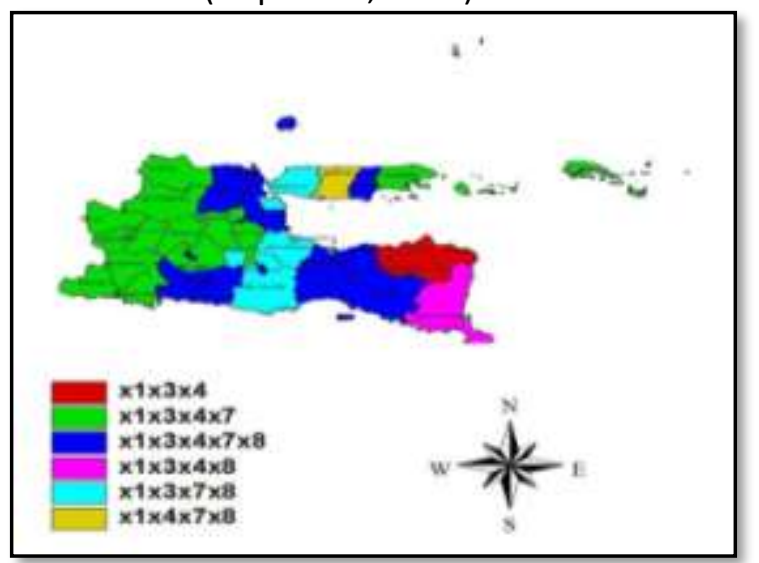

Gambar 1. Persebaran Variabel yang Signifikan terhadap Jumlah Kematian Bayi di setiap Kabupaten/ Kota

Pemodelan dengan menggunakan GWPR dapat menggambarkan variabel yang signifikan dengan lokasi pengamatan. Gambar 1 menunjukkan bahwa terdapat adanya pengelompokan variabel yang telah signifikan. Beberapa lokasi memiliki kesamaan variabel yang signifikan dengan lokasi yang berdekatan. Daerah yang berdekatan cenderung memiliki kesamaan karakter yang berpengaruh terhadap perilaku masyarakat. Lima macam pengelompokan kabupaten/kota didapatkan dengan 5 variasi variabel yang signifikan. Hal ini menunjukkan adanya perbedaan faktor yang berpengaruh terhadap jumlah kematian bayi antara wilayah satu dengan wilayah yang lain.

Kabupaten/kota yang signifikan terhadap kelima variabel pada pemodelan GWPR yaitu Kabupaten Tulungagung, Kabupaten Blitar, Kabupaten Lumajang, Kabupaten Jember, Kabupaten Probolinggo, Kabupaten Sidoarjo, Kabupaten Lamongan, Kabupaten Gresik, Kabupaten
Pamekasan, Kota Kediri, Kota Blitar, Kota Malang dan Kota Mojokerto.

Tabel 5. Pengelompokan Kabupaten/Kota Berdasarkan Variabel Signifikan yang Sama pada Model GWPR

\begin{tabular}{|c|c|}
\hline Kabupaten/Kota & $\begin{array}{l}\text { Variabel yang } \\
\text { signifikan }\end{array}$ \\
\hline $\begin{array}{l}\text { Kabupaten Bondowoso, Kabupaten } \\
\text { Situbondo }\end{array}$ & $\mathrm{X}_{1} \mathrm{X}_{3} \mathrm{X}_{4}$ \\
\hline $\begin{array}{l}\text { Kabupaten Pacitan, Ponorogo, } \\
\text { Trenggalek, Kediri, Mojokerto, } \\
\text { Jombang, Nganjuk, Madiun, Magetan, } \\
\text { Ngawi, Bojonegoro, Tuban, Sumenep, } \\
\text { Kota Madiun, Kota Batu }\end{array}$ & $\mathrm{X}_{1} \mathrm{X}_{3} \mathrm{X}_{4} \mathrm{X}_{7}$ \\
\hline $\begin{array}{llr}\text { Kabupaten } & \text { Tulungagung, Blitar, } \\
\text { Lumajang, Jember, Probolinggo, } \\
\text { Sidoarjo, } & \text { Lamongan, Gresik, } \\
\text { Pamekasan, Kota Kediri, Kota Blitar, } \\
\text { Kota Malang, Kota Mojokerto }\end{array}$ & $\mathrm{X}_{1} \mathrm{X}_{3} \mathrm{X}_{4} \mathrm{X}_{7} \mathrm{X}_{8}$ \\
\hline Kabupaten Sampang & $\mathrm{X}_{1} \mathrm{X}_{4} \mathrm{X}_{7} \mathrm{X}_{8}$ \\
\hline $\begin{array}{l}\text { Kabupaten Malang, Kabupaten } \\
\text { Pasuruan, Kabupaten Bangkalan, Kota }\end{array}$ & $\mathrm{X}_{1} \mathrm{X}_{3} \mathrm{X}_{7} \mathrm{X}_{8}$ \\
\hline $\begin{array}{l}\text { Probolinggo, Kota Pasuruan, Kota } \\
\text { Surabaya }\end{array}$ & \\
\hline Kota Banyuwangi & $\mathrm{X}_{1} \mathrm{X}_{3} \mathrm{X}_{4} \mathrm{X}_{8}$ \\
\hline
\end{tabular}

Perbandingan antara model regresi Poisson dan model GWPR dilakukan untuk mengetahui model mana yang lebih baik diterapkan untuk kasus jumlah angka kematian bayi di Provinsi Jawa Timur. Pemilihan model terbaik dengan menggunakan nilai AIC (Akaike's Information Criterion) dari kedua model tersebut. Model yang terbaik adalah model dengan nilai AIC terkecil.

Nilai AIC dari model GWPR sebesar 540,252505., sedangkan nilai AIC dari model regresi Poisson sebesar $1,176 \times 10^{3}$. Hasil perbandingan nilai AIC menunjukkan bahwa nilai AIC model GWPR lebih kecil dibandingkan nilai AIC regresi Poisson sehingga model GWPR lebih baik digunakan untuk menganalisis data jumlah kematian bayi di Provinsi Jawa Timur dibandingkan dengan regresi Poisson.

\section{SIMPULAN DAN SARAN Kesimpulan}

Jumlah kematian bayi di Jawa Timur tahun 2012 sebanyak 5905, rata-rata kematian di 38 Kabupaten/Kota sebesar 155 jiwa. Varian kasus 
kematian bayi di Jawa Timur relatif tinggi, hal ini dikarenakan terdapat daerah dengan jumlah kematian bayi mencapai ratusan jiwa namun ada juga daerah dengan jumlah kematian bayi relatif rendah hanya mencapai puluhan.

Pemodelan GWPR dengan fungsi kernel fixed Gaussian menunjukkan bahwa variabel yang signifikan hampir setiap Kabupaten/Kota yaitu pertambahan Produk Domestik Regional Bruto (PDRB), Angka Melek Huruf (AMH), persentase imunisasi dasar lengkap, persentase penolong persalinan non medis. Sedangkan faktor yang paling berpengaruh secara signifikan di seluruh kabupaten/kota di Jawa Timur adalah jumlah fasilitas kesehatan.

Perbandingan nilai AIC pada pemodelan GWPR lebih kecil dari nilai AIC pada model regresi Poisson sehingga dapat disimpulkan bahwa model GWPR lebih baik digunakan untuk menganalisis data jumlah kematian bayi di Provinsi Jawa Timur dibandingkan dengan regresi Poisson.

\section{Saran}

Secara keseluruhan variabel yang digunakan dalam penelitian tidak semuanya signifikan. Oleh karena itu saran yang direkomendasikan untuk penelitain selanjutnya yaitu diperlukan variabel lain sebagai variabel penduga yang lebih berhubungan dengan kematian bayi.

\section{DAFTAR PUSTAKA}

Badan Pusat Statistik. 2013. Laporan Eksekutif Kesehatan Provinsi Jawa Timur 2012. Surabaya: Badan Pusat Statistik Provinsi Jawa Timur.

Depkes RI. 2003. Profil Kesehatan Reproduksi Indonesia. Jakarta: Depkes RI.

IDAI. 2008. Pedoman Imunisasi di Indonesia. Jakarta: Penerbit Ikatan Dokter Anak Indonesia

Khudhori. 2012. Analisis faktor-faktor yang Mempengaruhi Keputusan Pemilihan Tempat Persalinan Pasien Poliklinik Kandungan dan Kebidanan Rumah Sakit IMC Bintaro. Tesis, Universitas Indonesia

Kumalasari, M. 2009. Analisis Pertumbuhan Ekonomi, Angka Harapan Hidup, Angka
Melek Huruf, Rata-rata Lama Sekolah, Pengeluaran Perkapita, dan Jumlah Penduduk Terhadap Tingkat Kemiskinan di Jawa Tengah. Tesis, Universitas Diponegoro.

Nakaya, T., Fotheringham, A.S., Brunsdon, C dan Charlton, M. 2005. Geographically Weighted Poisson Regression for Disease Association Mapping. Statistic in Medicine, Volume 24 Issue 17, page 2695-2717.

Pickett, George dan Hanlon, J. J. 2009. Kesehatan Masyarakat Administrasi. Jakarta: EGC.

Silalahi, B. 2011. Analisis Pengaruh Variabel Kependudukan Terhadap Harga Konstan di Kabupaten Jepara (19862008). Semarang: Universitas Diponegoro. 